\title{
Adam Smith's Green Thumb and Malthus's Three Horsemen: Cautionary Tales from Classical Political Economy
}

\section{Gareth Dale (draft)}

\begin{abstract}
This essay identifies a contradiction between the flourishing interest in the environmental economics of the classical period and a lack of critical parsing of the works of its leading representatives. Its focus is the work of Adam Smith and Thomas Malthus. It offers a critical analysis of their contribution to environmental thought and surveys the work of their contemporary devotees. It scrutinizes Smith's contribution to what Karl Polanyi termed the "economistic fallacy," as well as his defences of class hierarchy, the "growth imperative" and consumerism. It subjects to critical appraisal Malthus's enthusiasm for private property and the market system, and his opposition to market regulation. While Malthus's principal attraction to ecological economists lies in his having allegedly broadened the scope of economics, and in his narrative of scarcity, this article shows that he, in fact, narrowed the scope of the discipline and conceptualized scarcity in a reified and pseudo-scientific way.
\end{abstract}

Keywords. Thomas Malthus, Karl Polanyi, Adam Smith, ecological economics, natural capital, scarcity

In recent literature, academic and otherwise, on the political economy of "nature," an increasingly important reference point is the classical period of political economy - the roughly century-long era that was bookended by Adam Smith's Theory of Moral Sentiments and John Stuart Mill's Principles of Political Economy. It was a foundational period for the newborn discipline of political economy: an epoch that witnessed the consolidation of capitalism in Northwest Europe and its seemingly inexorable global expansion, a historic departure that saw rapid economic and population growth become the norm. In Europe, per capita GDP growth had crept upward at roughly 0.1 percent per annum from the sixteenth to the nineteenth centuries but, in the century that followed, it soared to around ten times that figure. By the mid-eighteenth century, when Smith published his Theory of Moral Sentiments, the notion that continuous "material progress" was possible and desirable was becoming commonplace in Britain, and the first treatise that set as its explicit goal the theorization of - what would nowadays be termed - economic growth was the same author's Wealth of Nations. For the classical economists, growth was ab initio a central concern. Yet, at the same time, they saw it as self-limiting - the rate of growth of capitalist economies would tend to decline over time - and this has enhanced their appeal to environmental scholars and campaigners in the present.

In mainstream economics today, the classical thinkers are cornerstones of the pantheon and some of their theorems are regarded as axiomatic. Yet, much of their contribution was buried by the neoclassical edifice that was constructed upon it in the late nineteenth century and beyond. This is regrettable, and a welcome contribution of ecological economics as it has developed over the last forty years, is that it has disinterred some of their ideas. Herman Daly 
(2007, 62), for example, cites Smith, Thomas Malthus, David Ricardo, and Mill as the thinkers from whom we still have the most to learn. This essay focuses upon the first two of these theorists. ${ }^{1}$ It provides a critical analysis of their contribution to ecological economics, and surveys the output of their contemporary admirers. The discovery of Smith's green credentials gathered pace during the 1990s and early 2000s, a period of relatively stable economic growth that also witnessed the mainstreaming of environmental issues. Malthus's name rang out more loudly in the 1970s, and again in the current age of economic upheaval and ecological emergency. This essay identifies a contradiction between the substantial degree of interest in the environmental political economy of the classical period, as manifested in a recent outpouring of publications by ecological economists and social theorists who take their cue from Smith and Malthus, and the dearth of critical parsing that has accompanied it.

\section{Adam Smith's Green Thumb}

If Malthus's name has long been a fixture in the literature on humankind's relationship to nature, the 1980s rise of liberal environmentalism - whose proponents believe that a sustainable society can best be realized by way of market forces, alongside scientific progress and individual consumer choice - brought another classical economist into the frame: Adam Smith. Bill Clinton is among the most prominent players to have yoked Smith's ghost to the environmental cause. In a 1992 lecture that spoke of the need to "bring powerful market forces to bear on America's pollution problems," he called for a new era in environmental protection, one that "uses the market to help us get our environment back on track - to recognize that Adam Smith's invisible hand can have a green thumb" (Clinton, in Levin and Landres 1992, 311-312). Although Clinton did not explore Smith's colourful digit in any detail, his vice president has done so. Describing Smith (rather eccentrically) as "the founder of capitalism," Gore $(2007,74,100)$ suggests that he provided a usable kit with which to design a sustainable capitalist order. Other scholars who have explored Smith's contribution in greater depth include the economist David Korten (1999), who dedicates his "ten rules to guide a healthy market economy" to the Scottish economist, and Paul Hawken, Hunter Lovins and her former husband Amory Lovins, who recruited Smith's spirit to sign their petition for "natural capitalism." For them, linking environmental challenges to profitable business opportunities is the name of the game. The key players are business leaders, for "they're the ones who can save the world fastest and make money on the deal" (Amory Lovins, on The Paula Gordon Show, n.d.; Hawken, Lovins and Lovins 1999). Companies will come to recognize that it is in their interests to develop eco-friendly practices and products, at which point markets can be left to create an "eco-efficient" economy. Mr. Lovins delights in putting "the fear of Adam Smith" into business leaders, showing that green innovators will, in all likelihood, steal a march on rivals, thereby presenting the latter with the choice of "going green" or losing market share (The Paula Gordon Show, n.d.). In line with this approach, Ms. Lovins's recently published Climate Capitalism (2011) envisions global warming as a mouthwatering opportunity upon which companies and consultancies can capitalize.

A more serious engagement with the work of Smith is elaborated in Capitalism As If the World Matters, by Jonathon Porritt - a friend of Amory Lovins, former chair of Britain's Green Party, and advisor to the British government on environmental issues. Porritt sets out to "reclaim the inheritance of Adam Smith." Introducing the Scotsman as the founding father of "moral capitalism," he "re-presents the case first made by Adam Smith that wealth creation should be so organized as to simultaneously optimize both profit and social wellbeing," and 
extends it to the claim that capitalism is "the only overarching system capable of achieving any kind of reconciliation between ecological sustainability and the pursuit of prosperity and personal wellbeing" (Porritt 2007, 279, emphasis added). Smith's achievement was to design a morally justifiable market economics, while championing individualism - as in the metaphor of the invisible hand. Porritt defends Smith against the charge that he advises individuals to "look out for Number 1" and leave the common good to take care of itself. The author of Moral Sentiments, he points out (2005, 43), enjoins heartfelt sympathy with the plight of others, advocates a market system not as an end in itself but as a means to enable individuals to lead fulfilling lives, and supports self-interested action only insofar as it is pursued by "people of conscience," informed by a capacity for moral awareness. If these traits are absent, the invisible hand of self-interest will fail to weave its magic. Porritt also speaks admiringly of Smith's support for state intervention to uphold fair competition and for universal public education, and of his concern over the potentially pernicious consequences of the rise of limited liability companies.

Perhaps unsurprisingly for the director of a limited liability company, Porritt's criticism of corporate capitalism is restrained, and he has no truck with the belief that shareholder and employee interests are opposed. However, he does express concern that boards of directors "are in thrall to institutions and individuals who have no concern for their companies, their products and services, let alone their employees or the communities in which they are based" (Porritt 2005, 182). This dysfunction rests in part upon "the myth of the amoral corporation and on the 'separation of functions' which allows the same person to behave one way in his/her business life and quite differently as a mother or father or "pillar of the local community" (Porritt 2005, 201).

Yet this - Porritt is adamant - is an institutional feature of "actually existing capitalism" alone, and is open to reform. An eminently feasible alternative arrangement would "validate the intuitive notion that employees' 'intellectual capital' is as essential to an enterprise's success as shareholders' invested capital" (Porritt 2005, 143). Far from being utopian, he insists, his vision draws direct inspiration from Smith's era, an age in which businesspeople "could be trusted not to harm the community in pursuing their self-interest - simply because of built-in restraint derived from morality, religion, custom and education" (Porritt 2007, 108). The age of the Scottish Enlightenment permits an insight into how we might design "an elegant form of capitalism that puts the Earth at its very centre and ensures that all people are its beneficiaries" (Porritt 2005, 324).

\section{Thomas Malthus and the Three Horsemen}

To environmental scholars and campaigners, Malthus needs no introduction, and for some he has the status of patron saint. The thesis for which he is known scarcely requires rehearsal: Since the contradictory outcomes of the drives for food and sex ensure that "absolute scarcity" is an inherent feature of human society, the poor will always be with us. By absolute scarcity I refer, following Daly, to a quantitative relationship between the requirements of human beings and available resources, as contrasted with relative scarcity, which denotes a situation of choice between desired alternatives (see Daoud 2010; Hodgson 2001, 278). Taking the fixed supply of land and the inevitability of population pressure as givens, Malthus theorized a version of the law of diminishing returns. As population expands, food production per agricultural labourer tends to decline, bringing starvation to the poor and lower population growth, tendencies that combine to decrease the rate of economic growth. Starvation figures as 
a "positive" check on population growth alongside two other apocalyptic horsemen - war and disease, but "preventive" checks (e.g., sexual abstinence) can produce a similar outcome with reduced suffering. In the first edition of his Essay on the Principle of Population, Malthus emphasizes the positive checks and denies that a long-term balance between population and food supply can be achieved. In the second, the "preventive" checks come to the fore, in support of a moralistic and meliorist vision of progress. Malthus's contribution, as Daly sees it (in Attarian 2003), is that he spelled out with unflinching realism the stark choice that all human societies face: "[I]f we don't adopt preventive checks then we will experience the positive checks (famine, war, plague)."

In the postwar era, the rediscovery of Malthus has followed several distinct pathways. His "orthodox" followers foreground the contradiction between human society's expanding population and the limited availability of food. They portray a "population explosion," construed as a kind of abstract force that must be halted, if necessary with coercive measures (Jamison and Eyerman 1994, 77). Others, at one remove, conjoin the population/food contradiction with wider issues of resource availability. At a further remove, the environmental degradation occasioned by economic and population growth is brought into the equation.

The first group, let's call them "orthodox Malthusians," includes Fairfield Osborn, William Vogt, and Hugh Everett Moore whose Road to Survival, Our Plundered Planet and The Population Bomb! ignited the Malthusian revival of the 1950s (Desrochers and Hoffbauer 2007). In the same decade Kenneth Boulding $(1956,118)$ introduced Malthusian elements into his holistic economics, with the 1845-1849 Irish potato famine presented as an illustration of Malthusian laws in operation. These thinkers revived what Larry Lohmann (2005) terms "daylight" Malthusianism - the thesis that there exists a quasi-logarithmic relationship between food and population growth - as well as the "Us versus Them" Malthusian terror narrative, in which the overbreeding poor threaten civilization and planetary survival. Vogt and Moore, in particular, injected apocalyptic urgency into the traditional Malthusian gloom, but they were soon to be outdone by Paul and Anne Ehrlich in their 1968 bestseller, also called The Population Bomb. A fair conspectus of the bleakness of their vision is contained in a comment on the three scenarios that the book sketches out (Ehrlich 1971, 77), the third of which, they remark, "has considerably more appeal than the others, even though it presumes the death by starvation of as many as a billion people" in just one decade. In certain respects, the Ehrlichs are, as William Easterly (2001) has dubbed them, Malthus's "latter-day incarnation," for they campaigned against population growth, expressed a barely concealed revulsion toward the poor, and sought to abolish the conditions that permit "communism and 'big government' to thrive" (Ehrlich 1971, 170). However, all this was spliced together with an easy-going Californian libertarianism that would have turned the Reverend purple. ${ }^{2}$ Society, say the Ehrlichs (1971, 134-135, 156), should cease to be "sexually repressive and repressed." After all, sex is "not primarily a mechanism of reproduction," but "an important and extremely pleasurable aspect of being human." The path to a brighter future, they add, has been revealed "by the 'hippie' movement - a movement wrapped up in Zen Buddhism, love, and a disdain for material wealth."

If the Ehrlichs's Malthusianism was libertarian, the same could not be said of his truest twentieth century follower, the zoologist and eugenicist Garrett Hardin. His "Tragedy of the Commons" (1968) advances an austerely Malthusian denunciation of the "freedom to breed." Malthus, Hardin concedes, was mistaken to believe that human populations are intrinsically inclined to grow more quickly than the available food supply. But his other central propositions were correct: Population does tend to increase exponentially and, for this reason, the decisive challenge facing human society is indeed the "population problem"; "exponential 
growth is kept under control by misery"; social well-being depends upon the ratio between the size of total population and the magnitude of available resources; and "overpopulation" is the fundamental cause of poverty (Hardin 1993, 9, 107, 187; Hardin 1998, emphasis in original).

The authors discussed so far, although interested principally in population, sought to revitalize the Malthusian tradition by supplementing its traditional fixation upon population and renewable resources (food) with a concern for non-renewable resource exhaustion, pollution, and the fragility of the world's ecosystems. Most environmental problems, as Hardin put it $(1993,5)$, "reduce to the single problem of balancing supply and demand," where supply (being dependent on nature) is "strictly limited" and demand (because human) is "essentially unlimited." Those strict limits were explored with particular rigor by Nicholas GeorgescuRoegen. An economist of Schumpeterian-neoclassical training, Georgescu-Roegen also found much of value in Malthus, above all, the recognition that the economic process is not isolated and self-sustaining but interconnected with "the biological growth of the human species," such that no economy can exist without a continuous interchange with the natural environment that alters the latter in a cumulative way (Georgescu-Roegen 1999, 317; 1976, 4). He furnishes this putatively Malthusian aperçu with a rigorous scientific basis, revealing the ultimate constraint on human economy to be the availability of low-entropy resources.

Georgescu-Roegen's magnum opus was swiftly followed by another seminal text that broadened the Malthusian case to encompass non-renewable resource utilization: the Club of Rome's Limits to Growth report of 1972. Although classically Malthusian in its warnings of "super-exponential" population growth and in its assumption that hunger results from the diminishing supply of food and not its distribution (Meadows et al. 1972, 34), The Limits to Growth did more than any other text to extend the Malthusian remit to the depletion of nonrenewable resources and the environmental deterioration that accompany industrialization. Among much else, it updated the law of diminishing returns for the industrial era: "Each unit of industrial output consumes some non-renewable resource reserves. As the reserves gradually diminish, more capital is necessary to extract the same amount of resource from the earth, and thus the efficiency of capital decreases" (Meadows et al. 1972, 101).

In the 1980s and 1990s, the neo-Malthusian revival stalled. But its "orthodox" variant endures as a permanent fixture in debates on population growth and projected food supply (e.g., Brown 2011), while broader Malthusian arguments remain influential within the wider environmental discourse. An illustrative example, once again, is Daly (in Attarian 2003), who proposes that we "extend Malthus' logic to populations of things as well as people - cars, houses, refrigerators," for their construction and maintenance "requires an entropic throughput from the environment - in other words, a load on environmental carrying capacity." On similar lines, Clive Hamilton $(2011,44)$ argues that the central problem that humanity faces has arisen

not from the old working-class vice of excessive copulation but the modern middleclass vice of excessive consumption. And just as . . Malthus recognized that the natural checks of famine and war could be avoided by 'moral restraint' in the form of [sexual] abstinence, so the answer to the climate crisis lies in disinterring the middleclass virtues of moderation and frugality.

Since the onset of global economic crisis in 2008, a pronounced uptick in Malthusian literature has been underway. Richard Heinberg's The End of Growth is a case in point. Although not an orthodox Malthusian, he holds $(2007,2011)$ that the English economist "was ahead of his time," and deploys Malthusian ideas to predict an imminent global economic 
collapse. Much in the manner of The Limits to Growth, Heinberg conceives of growth as dependent upon a particular set of natural resources that are non-renewable, irreplaceable, and in rapid decline. The underlying cause of the global crisis, he contends, is resource depletion, and because human society is now obliged to confront not merely Peak Oil but "Peak Everything" - from gallium and helium to palladium and phosphates, from the rare earths and tantalum to uranium and zinc - the end of global growth is nigh (Heinberg 2011, 144). Other recent publications that make similar claims include The World on the Edge (2011), The Crash Course: The Unsustainable Future of Our Economy, Energy, and Environment (2011) and the bombastically titled We Have to Change: Taking Action to Stabilize Climate Change, Curb Population Growth Including Immigration, End Poverty, and the Liquidation of Nature's Capital (2010). As the latter title reminds us, opposition to immigration retains a strong presence within the Malthusian tradition - as exemplified also by Daly, who sits on the advisory board of the anti-immigration "Carrying Capacity Network."

\section{"Natural Capitalism" and the Naturalization of Capitalism}

Daly is the most prominent representative of a trend that began with the Malthusian revival in the early 1970s but which has continued ever since, whereby neo-Malthusians, having found looming "limits to growth," identify as the remedy a "no-growth economy," also known as the "stationary state" or "equilibrium state" (Boulding 1973; Meadows et al. 1972). The stationary state was, of course, a familiar concept to Smith. He held that the potential wealth of any given society is constrained by its complex of laws and institutions, climate, and the extent of cultivatable land, and believed that some countries - he mentions China and Holland may already, in the eighteenth century, have acquired their "full complement of riches" (Smith 1993, 91-93). However, he does not advocate this as an ideal, for life in a "stationary state" would be dull, and in a "declining" one - melancholic (Smith 1993, 81). On the contrary, he speaks optimistically of the "natural progress of opulence." For him, growth is an unqualified good: It fulfils material needs and furthers human intercourse. It is democratic, benefiting all social classes alike; the "progressive state," in Smith's lexicon (Smith 1993, 9), is "the cheerful and the hearty state to all the different orders of the society."

In explaining economic growth, Smith famously invokes the natural propensity to truck and barter, as well as structural logics of specialization and marketization, but he also provides an additional argument grounded in consumer behaviour. Human beings, in their attempt to gratify their "love of distinction" (Smith 2009, 212), are prone to fall for a deception, namely that the accoutrements of wealth represent something genuinely grand and noble, and worth the toil and anxiety required to achieve them.

It is this deception which rouses and keeps in continual motion the industry of mankind. It is this which first prompted them to cultivate the ground, to build houses, to found cities and commonwealths, and to invent and improve all the sciences and arts, which ennoble and embellish human life. (Smith 2009, 214)

Some commentators maintain that in passages such as this Smith combines a modern argument in support of "the defenders of luxury," namely that the desire for luxuries motivates economic growth, with the notion that the illusory attractions of luxury bring no real happiness, an idea that aligns him with the ancient tradition that identifies luxury with artificial needs, excess, and venality (Brewer 2006). Others contend that Smith was making a 
thoroughly modern move in repositioning needs and desires as "conceptually indistinguishable," such that it is impossible "to separate, morally or conceptually, needs and luxuries." While viewing the benefits of riches with scepticism, Smith assumed human needs to be intrinsically insatiable rather than essentially stable (Lasch 1991, 52). In this reading, Smith is positing acquisitiveness as a natural condition - an axiom that Malthus also shared. Whichever interpretation is correct, Smith indubitably applauded human desire for its propensity to stimulate demand. Demand, he argued, moves the wheels of trade and wealth creation, exciting, in turn, the proliferation of further desires. In short, he originated the theory of consumer-driven capitalism with consumption postulated as "the sole end and purpose of all production" (Smith 1993, 376, emphasis added.) In this, he exerted a seminal influence on the ascendancy of the "growth paradigm" - by which I refer to the idea that economic growth is inherently good, imperative, and a matter of pressing concern for society as a whole. It is quite remarkable that less than fifty years after the appearance of The Wealth of Nations, Smith could stand accused, together with Malthus and Ricardo, of having reduced the science of political economy to the single narrow goal of cheerleading "the indefinite increase of the accumulations of wealth" (Thompson 1824, vi).

As we have seen, Smith assumed that growth would bring all-round benefit to society. But this did not preclude a defence of class hierarchy. Indeed, the "invisible hand" is introduced in his Moral Sentiments $(2009,215)$ as a defence of the social importance, and the individual incomes, of "the rich." It is an apologia that pivots on the premise that the material wealth they amass will spill over to benefit the common good - the so-called "trickle-down" effect. As to his Wealth of Nations, it served as a manifesto for the commercially minded gentry. Yet, whether they, or other late eighteenth century entrepreneurs for that matter, were prone to display the "restrained" and benign behaviour that Porritt claims for them is open to doubt. This was the age of "Old Corruption," of negligible environmental regulation, and paltry welfare provision. It was an age, moreover, of forced enclosures, of which the Highland Clearances were but the most infamous. In Scotland, Smith's target audience, improving landlords grasped his book with both hands, for it provided intellectual cover for their campaign to turn the Highlands over to sheep in the name of regional specialization. Far from producing democratic wealth and plural ownership, the Clearances brought about the annihilation of crofting communities and the monopolization of land by a handful of (often absentee) landlords (Richards 1985). As property, including landed estates, became increasingly alienable, nature's "taps" were privatized and its "sinks" left to the public sphere - this was the true "tragedy of the commons."

In applying Smithian ideas to the present day, Porritt's spectacles are not quite so rosetinted. He recognizes that ethical behaviour by businesspeople comes up against limits that are set by "corporate bureaucracy; by the power of capital markets; . . . by procrastinating politicians," and he concedes that corporations are "compelled to cause harm where the benefits of doing so outweigh the costs" (Joel Bakan, in Porritt 2005, 72). His proposed remedy to such ills lies in legislation that obliges corporations to internalize externalities. Yet, in reality, he is candid enough to admit that $(2005,72)$

governments are less and less inclined to introduce, let alone to enforce, new regulations that are invariably opposed by business and their trade associations. Governments in the rich world are not so much the ringholders between civil society, on the one hand, and corporations intent on making other people pay their bills, on the other; more and more, government and business seem to be working as partners. 
We must, therefore, recognize our interdependence, Porritt proposes. For a sustainable capitalism to function,

a feedback mechanism needs to be in place; people need to be able to see the effects of their actions on others. ... Sustainable development is a global problem and the effects of our actions are often indirect, taking place thousands of miles away. For values to develop that are aligned to sustainable development, adequate feedback mechanisms are required - mechanisms that nurture empathy, and that allow us to witness global problems and connect them to their cause.

How realistic is this within a capitalist global order? One of the reasons Porritt holds Smith in such high regard is that he theorized the symbiosis of efficiency gains and social cooperation and interdependence. On the world scale, this translates into the thesis that economic globalization generates and benefits from the rise of a global civil society. Yet, in practice, capitalism appears able to produce only a wafer-thin cosmopolitanism, for it divides the (world) economy into discrete units of value, whose systemic competition blocks the very feedback mechanisms that Porritt posits as indispensable to sustainable development. When core aspects of human life - indeed of humanity's metabolism with nature - are structured into the systemically rivalrous competition between firms and states, little is possible by way of democratic control over the social production and distribution of wealth. The point has been explored by Karl Polanyi (1936) with a pointed allusion to Smith. In capitalist society, "the life of man as a producer and consumer is organised so as to make egotism and greed into the only rational attitude allowed by circumstances." Human beings "are connected to each other by way of a Centre," with which each is connected, as spokes to a hub, "without being connected with each other. The strings that bind them together all run through the Market. The market isolates one person from another [even as] it connects goods with each other."

Elsewhere, Polanyi elaborates the point with a reference to Chateubriand's "killing a mandarin” fable. Readers are invited to imagine a machine which, upon the push of a button, grants them the fulfilment of their every wish, albeit at a price: Each time the button is pressed, one person within the population of faraway China will perish. The parable, in Polanyi's view (2005, 153-154),

provides an exact allegory of the relationship towards his fellow citizens of even the best of people in today's world. Whoever is able to bid the appropriate market price can at once conjure up everything that humanity can supply. The consequences of the trick are felt in the nether world beyond the market. He . . . cannot see them. For individuals today, humanity in its entirety consists of the anonymous Chinamen whose lives can be erased without so much as blinking an eye, whose lives will be erased in order to satisfy one's desires.

With society atomized into market actors, and with its economic and political spheres institutionally separated, humanity cannot set itself agreed goals or unfold its powers in concert.

In Polanyi's reading, Adam Smith is no neoliberal avant la lettre. His theory does not rely upon an assumption of self-interested individualism. Nor is there the slightest intimation that society either is or should be ruled by the economic interests of capitalists, nor any sense of "the economy" as a separate entity subject to laws of its own that furnish citizens with a standard of good and evil. Rather, in the spirit of the Scottish Historical School, Smith 
conceives of man as a social and moral being; a member of the civic order of family, state, and society. And yet, if in this sense his thought was wrapped in the ideational fabric of an earlier age, Smith also sharpened the knife that was shortly to slice it to shreds. In discovering the market's role as the pivot of economic life and the spur to competition, and in originating the myth of man's innate propensity to barter and exchange, he gave a decisive impetus to a new concept of society: atomistic in structure, with each atom a self-interested "Economic Man," oriented solely to the maximization of gain (Polanyi 1956). Glued to the precepts that a complex division of labour implies market exchange and that humans are by nature marketoriented beings, Smith assumed pre-capitalist societies to have been rudimentary forms of market society, when the latter is, in fact, a historical singularity.

In this way, Smith committed, and helped to originate, what Polanyi calls "the economistic fallacy," and thereby to the "naturalization" of capitalism. Smith, as Polanyi's friend and compatriot István Mészáros explains (2011, 279, 297), manages "to vindicate the "eternal present" of the bourgeois epoch because, at the level of method, he treats labour as well as the division of labour, capital, and rent, as forms of appearance of human productive powers in general, rather than as historically specific phenomena. In replicating this trick, Smith's latterday disciples faithfully follow his example. Thus, Natural Capitalism proposes that there exist two basic forms of capital, "money and goods," which are joined by "two even more vital ones: people and nature" (Lovins 2007). Money and goods denote financial capital (securities, bank notes, etc.) and physical capital (equipment and infrastructure that contributes to the commodity production process), while "people" (or "human capital") is constituted by the health, knowledge, skills, and motivation of workers. "Natural capital" refers to any stock or flow of energy and matter that yields marketable goods and services - thus, a forest is potentially natural capital insofar as it can be opened for tourism or felled and its contents sold. Porritt $(2005,112)$ extends the concept of capital further still, with "social capital" and "spiritual capital" supplementing the quartet of Natural Capitalism. With capital understood liberally as "a stock of anything that has the capacity to generate a flow of benefits which are valued by humans," social capital is defined as structures, networks, relationships, and institutions (such as families, businesses, states, charities) that enable individuals to develop their human capital and to cooperate productively with others. Spiritual capital, for its part, refers to "shared meanings and values and ultimate purposes." Defined thus, capital comprises financial capital together with the entirety of humanity's productive powers, insofar as they contribute in any way to the generation of monetary revenues. In this fashion, the existing social order is "naturalized" so that its endpoint would logically imply the end of human society - an apocalyptic Menschheitsdämmerung, in Elmar Altvater's resonant phrase (2005, 27). With this sleight of hand, radical criticism of capitalism is deemed inadmissible and "Žižek's paradox" is reinforced: that it is harder to imagine a radical change in capitalism than the end of life on earth.

\section{The Limits to Malthus}

One cannot study the oeuvre and influence of Malthus without coming up against a puzzle. On one hand, he stands accused of wilful obfuscation, intellectual delinquency, and serial imitation, not to say plagiarism. ${ }^{4}$ The "natural" limits to population growth were discussed by the ancient Greeks, as well as by Machiavelli and Smith. Benjamin Franklin spoke of the tendency of certain populations to increase "geometrically," and most of the other ideas that made Malthus's name had been adumbrated earlier by Richard Cantillon, James Steuart, 
Robert Wallace, Joseph Townsend, and Edmund Burke. ${ }^{5}$ On the other hand, his followers whether "orthodox" or not - insist that his "law of population" represented an original and historic advance in scientific understanding, and dismiss the accusation of plagiarism as exaggerated or irrelevant. They maintain, moreover, that his central theses - that prosperity causes population growth and that population growth tends ineluctably to outstrip the available food supply - remain correct. They express surprise that his views encounter "extreme hostility," and muse that this can only be due to the critics' "anthropocentrism" and their subscription to an "ideology of Progress [which] must be indefinite or not at all" (Curry 2011, 201).

Yet, when reading Malthus, one searches in vain for any challenge to "anthropocentrism" or the "ideology of progress" or, for that matter, to the exploitation of the earth's resources. Although he made his name by castigating the utopian perfectionism of radicals such as Condorcet and Godwin, for him, the future did not preclude a "gradual and progressive improvement in human society" (Levin 1966, 104), and he could "easily conceive" of substantial growth of population and of its welfare (McNally 1993, 82). Indeed, he held that a country could "go on increasing in riches and population for hundreds, nay, almost thousands of years" (Malthus 1989, 43, 437). He shared Smith and Ricardo's enthusiasm for economic growth and their belief that raw materials exist in abundance. Providing ammunition to critics of his latter-day disciples, he insisted $(2006,75)$ that "there is an essential difference between food and those wrought commodities, the raw materials of which are in great plenty. A demand for these last will not fail to create them in as great a quantity as they are wanted." He shared the consensus of his time that humanity was pursuing a path of progress from savagery to civilization. This was principally with respect to intellectual and moral capabilities, but Malthus added a proto-eugenic argument that foresaw the selective breeding of bigger and stronger human bodies, too (Levin 1966, 103). According to his theodicy, the Supreme Being's cardinal command is that mankind fully cultivate the earth. The divinely designed laws of nature operate in fulfilment of this plan - and it was in this way that the contradiction between population growth and food supply arose, for it is ordained by natural law precisely in order to encourage civilizational progress. Malthus's view of working people places extraordinary emphasis upon their sloth, which he saw as a regrettable drag upon the accumulation of capital, and he railed against measures, such as the poor laws, that risked alleviating poverty and thereby lessening the motivation to work among the lower orders (Mirowski 1985). Thus, the law of population acts as a divinely fashioned implement to spur human beings, naturally indolent as they are, to develop civilization. In this fashion, Samuel Levin comments (1966, 99), Malthus "wove the threads of a theory of mind, colored by his theological preconceptions," into the very fabric of his discourse on population.

Although centrally concerned with scarcity, Malthus was also troubled by "abundance," in the restricted sense of the overproduction of goods relative to effective demand. Alongside Simonde de Sismondi, he was the first to postulate underconsumption as the principal cause of economic crisis, although, unlike his Swiss contemporary, his proposed remedy lay in upping the spending power of the class of unproductive consumers - aristocrats, bureaucrats, parsons, and the like (Malthus 1836, 413-414). The power to consume should be withheld from the lower classes in the name of controlling the pressure of population on resources, while the upper classes should consume as heartily as they can in order to sustain aggregate demand.

The thrust of Malthus's new political economy was unambiguous: The market should function as a disciplinary mechanism to enforce scarcity upon the poor and channel abundance to the rich. A social system based upon private property and the division between a class of proprietors and a class of labourers, he wrote $(1836,349 ; 1989,202)$, will and should 
prevail for eternity, no less, during which time the priority of government must be to assure "the perfect security of property," given that this is among "the greatest sources of prosperity." Political regulation that interferes with the market could only be counterproductive, for the cause of poverty, as his principle of population purported to show (Malthus, in Hartmann 2010, 49), "has little or no direct relation to forms of government, or the unequal division of property; and that as the rich do not in reality possess the power of finding employment and maintenance for the poor, the poor cannot, in the nature of things, possess the right to demand them." This is why Malthus campaigned unflaggingly against the pre-1834 poor laws, for they interfered with the self-regulating mechanisms that enforce deference, self-discipline, and reproductive prudence upon the working population.

Malthus's influence extended far beyond Britain's shores. He issued policy recommendations on population control - for example, in reference to emigration from Ireland, he advised that as the poor leave its shores their cottages should be destroyed. Through his position at the East India Company, he taught a generation of future administrators of the empire about the "perils of overpopulation" and the "pointlessness of charity" (Grampp 1974, 296). They implemented his principles around the world - in India on a genocidal scale, as Mike Davis (2001) has documented. A student of Malthus, Charles Trevelyan, was a colonial governor who implemented his master's famine policy in 1840s Ireland, resulting in hundreds of thousands of avoidable deaths (O'Flynn 2009; Pearce 2010). Far from being a demonstration of population laws in operation, as Malthusians believe, the famines in India and Ireland demonstrated that Malthus's law - that the penalty for "overpopulation" should and must fall upon the poor - becomes a self-fulfilling prophecy when those who believe in it exercise power over the lives and livelihoods of others.

Given the Surrey parson's worldview and impact, it is puzzling that he commands the admiration of ecological economists. For them, the heart of his attraction is that he is thought to have widened the scope of economics. This is avowedly so for Georgescu-Roegen and Daly, and other Malthusians would doubtless concur. But it is a problematic assertion. In what sense could "economics," narrow or otherwise, have existed in his day? Malthus was the world's first professor of political economy and the first professional economist. Given that the discipline was in statu nascendi, whether Malthus could have "widened" its scope is an empty question. The salient issue, rather, is whether or not it was to be founded upon a "broad" or "narrow" methodological basis. Smith leaned toward the former and included institutions, social relations, and ethics in the frame. While attempting to put the discipline on a scientific footing, he insisted upon its inextricable connections to the sciences of statecraft and jurisprudence, and to moral philosophy. Malthus's contemporary, Sismondi, developed a more holistic and institutionalist approach. He offered a critique both of "the formalism and abstractedness" of the Malthusian/Ricardian mainstream and of the market system itself: of its illusory "false prosperity," the domination of social life by the profit motive, and its myriad negative effects (the ruin of small enterprise, the exodus from the countryside, and the displacement of workers by machines) (Romani 2005). Criticizing the extravagant "fantasies" of the rich, Sismondi advocated the "simple life" and proposed that a viable economy should centre upon the "numerous class of peasant proprietors," together with artisans catering to local, regulated markets (Luxemburg 1971, 174-177, 190; Romani 2005; Sismondi 1991, 339, $569,573,577)$. One might think his work would be a natural port of call for ecological economists, but it was marginalized by the Malthus-Ricardo tradition and its neoclassical progeny.

In his method, Malthus did not proceed along the positivist road as far as his neoclassical descendants were to travel, and he was even prepared to entertain the Smithian precept that 
"the science of political economy bears a nearer resemblance to the sciences of morals and politics than to the science of mathematics" (Malthus 1836, 434). However, he did proceed further than any of his peers. He did his utmost to ensure that political economy would be configured as "a positive science, founded on experience," and that its scope should include only material goods - for only they can be measured (Malthus, in Rist 2011, 119). His belief that social institutions "are mere feathers that float on the surface" (Malthus, in McNally 1993, 76) and his related argument that because economic behaviour rests upon a biological basis it should be modelled as such, contributed to the exclusion from the new discipline of considerations of the relationship between markets, on the one hand, and ethics and social institutions, on the other, as well as to the marginalization of those who thought otherwise Sismondi, Robert Owen, and Marx. In sharp contradistinction to earlier positivist philosophy, which had won its spurs in the eighteenth century as a critical revolutionary movement pitting science and human reason against absolutism and organized religion, Malthusian positivism was reactionary and reductive - above all, in its contention that social phenomena can and should be reduced to natural-scientific "laws of life." By invoking biology in support of the supposed necessity of wage repression, he sought to cast political economy in the mould of a natural science; the market society that he endorsed was to be founded, as Polanyi put it (1957), "on the grim realities of Nature." But the laws of this "nature" were largely decreed by Malthus's imagination and - what amounts to the same thing - the "science" he espoused was little but theologically driven scientism. (It is an approach that his followers have taken to heart. Hardin's "Tragedy," for example, is structured around a disinterred fable confected by a Malthusian parson in the 1830s. ${ }^{6}$ ) That Malthus clung to his "law" of population when every passing year announced its empirical refutation testifies not merely to dogmatism but, more importantly, to the non-falsifiability of its core proposition: the prognosis that "one day" population pressure will reduce per capita output. Malthusian theory, as Mark Blaug observes (in Dugger and Peach 2009, 45), "cannot be refuted because it cannot be applied to any actual or any conceivable population change: It purports to say something about the real world but what it says is true by definition in its own terms." Despite its positivism, it is pseudo-scientific, in the Popperian definition.

Malthus's selection of positivist pseudo-science as the method of economics does not, in itself, explain his appeal to ecological economists. A central piece in the jigsaw is his seminal influence on the foundational axiom of the nascent discipline: the ubiquity of scarcity. Before Malthus, the concepts of scarcity (and its synonym, "limits") had not been neglected by scholars of economy and society. John Locke, for example, pronounced that "whenever either the desire or the need of property increases among men, there is no extension, then and there, of the world's limits," which led him to conclude that "it is impossible for anyone to grow rich except at the expense of someone else" (in Wolin 1960, 318). But scarcity, Sheldon Wolin (1960) tells us, did not constitute a basic presupposition of bourgeois thought until "the alliance with economics" had been secured. Malthus and Ricardo were key players in forging that alliance. They thereby contributed to what Nicholas Xenos (1989) has termed the "invention of scarcity." Xenos focuses upon the way in which the increased role of markets in Georgian Britain destabilized traditional social arrangements and injected fluidity into the status order, giving rise to a new social landscape of fashion-driven competitive consumption. What his account misses is that the same period was also witnessing the final stages of a dramatic shift from a world of custom and common land to one based on absolute private property, with peasants driven from the land. In the countryside around Malthus's parsonage and beyond, ordinary people were being "literally excluded by fences enclosing the common lands that had sustained them for centuries" (Boal 2010). Scarcity was being produced, in the form of their 
welfare needs, and it is this that formed the basis of the moral panic, the flames of which Malthus was so keen to fan. Rather than theorize the production and distribution of scarcity, he sought instead to naturalize it by locating its cause solely and exclusively in purportedly "natural" facts: the sloth of working people and the constrained supply of cultivable land. In this way, scarcity came to be posited as the inevitable condition of economic life upon which the self-regulating market was based. Remove it and you remove the fear of hunger that spurs the labourers to work and to adhere to Christian prescriptions of thrift and sexual abstinence. Malthus's genius was to conscript the new invention, scarcity, to a normative and deeply reactionary political program. He did so by positing it as a force of nature.

Malthus played a pivotal role in elevating scarcity to the sacrosanct status that it thenceforth enjoyed, in successively modified forms, in the Millian and, later, neoclassical orthodoxies. From this vantage point, the Malthusian and neoclassical traditions are united in opposition to alternative, critical currents such as those associated with Marx or Polanyi. In Polanyi's analysis, scarcity is an empirical and socially constructed phenomenon; its presence depends upon natural and social factors and cannot be assumed a priori. Citing Aristotle, he contends that insofar as the scarcity postulate springs "from the demand side," it is attributable "to a misconceived notion of the good life as a desire for a greater abundance of physical goods and enjoyments" (Polanyi n.d.; 1977, 28; 1953; 1968, 98). Crucially, it cannot be assessed independently of its meanings in a given cultural context. In modern market economies scarcity becomes generalized. Given such an economy, consisting of a sequence of scarcityinduced choices taken by instrumental utility-maximizers, the assumptions of Malthusian and neoclassical economics come to appear as common sense, but these conditions do not obtain transhistorically. Polanyi (late 1950s) offers the example of the Trobriand Islanders who "grow normally twice as much yam fruit as they need and allow it to rot." They phrase their economic life "in terms of plenty, while according to our standards we are surrounded by scarcity. We, according to their standards, are surrounded by plenty but phrase our economic life in terms of scarcity."

Marx, similarly, treats scarcity not as an autonomous category denoting the universal relative scarcity of goods vis-à-vis human wants, but in relation to historically specific sets of relations and forces of production, distribution, consumption, and so forth. His explanation of the scarcity of employment within capitalism is based upon a sociological explanation centred on analysis of the concentration of the means of production in the hands of capitalists who are constrained to behave according to the logic of profit and competition (Perelman 1979, 83; see also Mészáros 2011, 442-450). Under different social relations, according to his prospectus, sufficiency, or even abundance, could realistically be achieved for all in the form of food, water, and energy to meet the needs of the human population, as well as in ample provision of health care, transportation and housing, and in means of education, recreation and self-expression.

With the advent of neoclassical economics, "scarcity" subdivided into "absolute" and "relative" forms, with the former denoting the actual use or existence of a resource in relation to requirements, and the latter referring to the alternative uses of resources in relation to competing wants (Daoud 2010). This distinction underpins the manifold philosophical and policy differences between the neo-Malthusian and neoclassical traditions. Malthusians emphasize the natural limits of resources, set great store by population control, and tend to a pronounced scepticism toward technological remedies. For the neoclassical tradition, scarcity plays a role not so much in its methodology and substance, but in the definition of its subject matter (as the science of resource allocation among competing goals in a situation of scarcity), and as a "legitimizing device for the general application of the technical apparatus and formal deductive methods of mainstream economics" (Fine 2010, 81). Nonetheless, its tone and 
scope are unmistakably Malthusian. Common to both traditions are the unquestioned assumptions that scarcity, being the outcome of the contradiction between the infinity of society's wants and the finitude of productive potential at its disposal, is natural, essential to the human condition, and the driver of the economic process. Common to both is the assumption that needs and wants are not socially constructed but "givens," rooted in the hedonism of individual consumers. Malthus believes that needs are fixed in human nature, while neoclassical economics, in reducing consumption to a relationship between the abstract "household" and the world of objects, implicitly denies their sociality (Matthaei 1984). By framing scarcity as an inherent characteristic of resources, Adel Daoud (2010) and Steve Rayner (2010) have argued, both traditions ignore the socially produced character of scarcity and the possibility of "states of abundance and sufficiency," and, in so doing, they naturalize the failure of societies to provide for the needs of their populations. Scarcity comes to function as a rationale for inequitable allocation, for the justification of skewed access to control over finite and limited resources, and for the diversion of attention away from causes of poverty and inequality that may implicate powerful groups (Mehta 2010).

Malthus, in this analysis, prefigured the neoclassical turn in economics in two principal respects: his reductive positivist methodology and the elevation of scarcity to the discipline's axial concept. All that was required for Malthusianism to transmogrify into neoclassical economics was for scarcity to divide into its "absolute" and "relative" forms, for Malthus's proto-marginalist value theory to relinquish its Smithian remnants, for biological reductionism to metamorphose into psychological reductionism, and for a few terms to be updated (workers' natural idleness as "the disutility of labour," and so forth). Thus, when Philip Mirowski remarks- in a characteristically gnomic aside - that "ultimately, Georgescu-Roegen has been unwilling to make a clean break with his erstwhile identity as a neoclassical economist; and it is this that explains the gaps and silences in his otherwise formidable works," one such silence, I would venture, concerns "the limits to Malthus." For it is only when viewed through the reversed telescope of neoclassical economics that Malthus can be praised for having widened the purview of political economy, when it is quite apparent that he achieved the opposite.

That Malthus's critics jeer at his plagiarism and his proclivity to contradict himself, in this light, is not mere sniping but gestures towards an issue of importance. By drawing attention to his intellectual shortcomings, critics are raising the question of why, in that case, his influence is immense and enduring. To this question, the short (biographical) answer is that, even as he chopped and changed his theoretical framework, Malthus stuck doggedly to his core manifesto: inequality is eternal; the distribution of goods should be left to the market; the poor must never be subsidized by the public purse. The longer (sociological) answer is that he provided an economic-liberal apology for free-market capitalism as it was consolidating in early nineteenth century England, and a neo-conservative defence of private property and social inequality as these were facing burgeoning challenges from 1789-inspired radicalism and nascent socialist and anarchist currents. In opposition to these movements, his arguments served, as Larry Lohmann has argued $(2005,95)$, to bolster and reinvent "the elite fashion of identifying the poor's plight as their fate by using mathematics to explain why the killings troubling his society were unavoidable. The oppressed were recast as sacrifices, and those who scapegoated them as upholders of society."

By appealing to the natural "facts" of scarcity and human egotism, Malthus was able to bring the authority of natural science to an otherwise eminently contestable chain of reasoning: that the contradiction between the infinitude of human wants and the limits of the land gives rise to economic life; that individuals invariably seek as large a share of nature's feast as possible, necessitating private property; and that relative valuations differ, so individuals 
exchange on markets, ergo economic activity is to be understood as the striving of individuals to maximize utility by minimizing labour expended and maximizing profit. Markets, private property, and utilitarianism, according to this logic, are ordained by natural law (Matthaei 1984). These arguments translated into unambiguous policy prescriptions - notably the 1834 Amendment - and, simultaneously, steered the nascent discipline of political economy onto a positivist track that pointed directly towards the neoclassical economics of the 1870s and beyond. As the founding father, with Ricardo, of a successful "social movement from above," one that rapidly achieved hegemony following its coup of 1834 and provided the script for a new mode of governance, Malthusian ideas soon acquired "common sense" status.

\section{Conclusion}

In this essay I have introduced and developed a critique of the environmentally relevant theses on growth and scarcity of the two most influential classical economists, Smith and Malthus. The essay draws attention to the way in which their views constructed and shaped the discipline of economics, to the exclusion of alternatives - Marxism and "old institutionalism" - that have more to offer to ecological political economy. The work of ecological economists who gain inspiration from Smith and Malthus is, understandably, focused upon real-world processes and debates. Nonetheless, their lack of systematic critical scrutiny of their forebears' work is disappointing. An apposite recent example is a book by Daly $(2007,62)$ that professes "to show that ecological economics has deep historical roots in classical economics," including Smith and Malthus, but fails to cash out this promise.

This is not an issue of merely theoretical concern. As Mark Blyth has noted (2002), economic ideas are potent instruments used by political actors to effect change, "since whoever defines what the economy is, what is wrong with it, and what would improve it, has a profound political resource in their possession." That Smith contributed in no small way to the consolidation of the "economistic fallacy," as well as authoring profoundly influential defences of class hierarchy, and the "growth imperative" and consumerism, is a problem that his ecologically-minded devotees would do well to confront head on. Similar applies to Malthusians. Their guru not only shared Smith's enthusiasms for economic growth, the market system and class division, but also opposed political regulation in markets, contributed more than any other economist to the casting of the discipline in a utilitarian and positivist mould, and constructed a narrative of scarcity and poverty that entirely edited out their socio-political causes.

\section{Notes}

1. I discuss Mill and Marx in Dale (2013).

2. For Malthus $(1817,393)$, artificial methods of birth control are "immoral" and tend to "remove a necessary stimulus to industry" by "increasing the indolence of the human race."

3. In recent writings, Daly $(2007,210)$ has lamented the tendency "of the environmental movement to court "political correctness" by soft-pedalling issues of population [and] migration."

4. The least of these charges, obfuscation, was famously put by John Stuart Mill (in Hollander 1997, 6), who accused Malthus of rendering "intricate that which is simple, obscure that which is clear, and difficult that which is easy." 
5. See Burke $(1800,2)$, "the labouring people are only poor, because they are numerous ... numbers in their nature imply poverty" - and passim; Townsend (1971, 36-42); Franklin (2011). See also Nitti (1976), Hartwick (1988), Lumley and Armstrong (2004, 369).

6. Lloyd (1833, esp. 30-33). That Hardin's piece appeared in a journal called Science turned "Tragedy" into dramatic irony.

7. Mirowski $(1988,827)$. Similar applies to Daly who, like his Romanian teacher, served a long and distinguished apprenticeship as a neoclassical economist.

\section{References}

Altvater, Elmar. Das Ende des Kapitalismus, wie wir ihn kennen: Eine radikale Kapitalismuskritik. Westfälisches Dampfboot, 2005.

Attarian, John. "A Conversation with Herman Daly." Social Contract 13, 3 (2003): pp. 155-162. Available at www.thesocialcontract.com/artman2/publish/tsc1303/article_1139.shtml. Accessed July 18, 2011.

Blyth, Mark. Great Transformations: Economic Ideas and Institutional Change in the Twentieth Century. Cambridge: Cambridge University Press, 2002.

Boal, Iain. "Specters of Malthus: Scarcity, Poverty, Apocalypse." Reimagining Economics. Available at www.economics.arawakcity.org/node/519 2010. Accessed July 18, 2011.

Boulding, Kenneth. The Image: Knowledge in Life and Society. Ann Arbor: University of Michigan Press, 1956.

—. "The Shadow of the Stationary State." Daedalus 102, 4 (1973): 89-102.

Brewer, Anthony. 'On the (other) invisible hand....' Available at www.efm.bris.ac.uk/economics/working_papers/pdffiles/dp06594.pdf 2006. Accessed 18, 2011.

Brown, Lester. "The New Geopolitics of Food,” Foreign Policy, May/June, 2011.

Burke, Edmund. Thoughts and Details on Scarcity, London: F. and C. Rivington, 1800 [1795].

Curry, Patrick. Ecological Ethics: An Introduction. Second edition. Polity, 2011.

Dale, Gareth. "Critiques of Growth in Classical Political Economy: John Stuart Mill's Stationary State and a Marxian Response." New Political Economy (forthcoming in 2013).

Daly, Herman. Ecological Economics and Sustainable Development, Selected Essays of Herman Daly. Edward Elgar, 2007.

Daoud, Adel. "Robbins and Malthus on Scarcity, Abundance, and Sufficiency: The Missing Sociocultural Element." The American Journal of Economics and Sociology 69, 4 (2010): 1206 1229.

Davis, Mike. Late Victorian Holocausts; El Niňo Famines and the Making of the Third World. London: Verso, 2001.

Desrochers, Pierre and Christine Hoffbauer. "The Postwar Intellectual Roots of the Population Bomb." Electronic Journal of Sustainable Development. Available at www.ejsd.org/public/journal_article/12 2007. Accessed July 18, 2011.

Dugger, William M. and James T. Peach. Economic Abundance: An Introduction. Armonk, NY: M.E. Sharpe, 2009.

Easterly, William. The Elusive Quest for Growth: Economists' Adventures and Misadventures in the Tropics. Cambridge, MA: MIT Press, 2001.

Ehrlich, Paul. The Population Bomb. New York: Buccaneer Books, 1971. 
Fine, Ben. "Economics and Scarcity: With Amartya Sen as a Point of Departure?" In The Limits to Scarcity: Contesting the Politics of Allocation, edited by Lyla Mehta, pp. 89-107. London: Earthscan, 2010.

Georgescu-Roegen, Nicholas. Energy and Economic Myths: Institutional and Analytical Economic Essays. Oxford: Pergamon, 1976.

- The Entropy Law and the Economic Process. Cambridge, MA: Harvard University Press, 1999 [1971].

Gore, Al. The Assault on Reason. London: Bloomsbury, 2007.

Grampp, William. "Malthus and His Contemporaries." History of Political Economy 6, 3 (1974): 278-304.

Hamilton, Clive. Requiem for a Species: Why We Resist the Truth about Climate Change. London: Earthscan, 2011.

Hardin, Garrett. "The Tragedy of the Commons." Science, New Series, 162, 3859 (1968): 1243 1248. Available at www.cs.wright.edu/ ${ }^{\sim}$ swang/cs409/Hardin.pdf 1968. Accessed 18 July 2011.

—.Living Within Limits: Ecology, Economics and Population Taboos. Oxford: Oxford University Press, 1993.

—. "The Feast of Malthus: Living within Limits." Social Contract. Available at www.garretthardinsociety.org/articles_pdf/feast_of_malthus.pdf 1998. Accessed July 18, 2011.

Hartmann, Betsy. "The Ghosts of Malthus: Narratives and Mobilizations of Scarcity in the US Political Context." In The Limits to Scarcity: Contesting the Politics of Allocation, edited by Lyla Mehta ,pp. 49-68 London: Earthscan, 2010.

Hartwick, John. "Robert Wallace and Malthus and the Ratios." History of Political Economy 20, 3 (1988): 357-379.

Hawken, Paul, Amory Lovins and Hunter Lovins. Natural Capitalism: Creating the Next Industrial Revolution. New York: Little Brown, 1999.

Heinberg, Richard. Peak Everything: Waking Up to the Century of Declines. Gabriola Island: New Society, 2007.

- The End of Growth: Adapting to Our New Economic Reality. Gabriola Island: New Society, 2011.

Hodgson, Geoffrey. How Economics Forgot History: The Problem of Historical Specificity in Social Science. London: Routledge, 2001.

Hollander, Samuel. The Economics of Thomas Robert Malthus. Toronto: University of Toronto Press, 1997.

Jamison, Andrew and Ron Eyerman. Seeds of the Sixties. Berkeley: University of California Press, 1994.

Korten, David. The Post-Corporate World: Life after capitalism. San Francisco: Berrett-Koehler Publishers, 1999.

Lasch, Christopher. The True and Only Heaven: Progress and Its Critics. New York: Norton, 1991.

Levin, Robert and Shawn Landres eds. Bill Clinton: The inside story. New York: S.P.I. Books, 1992.

Levin, Samuel. "Malthus and the Idea of Progress." Journal of the History of Ideas 27, 1 (1996): 92-108.

Lloyd, William. Two Lectures on the Checks to Population. Oxford, 1833. 
Lohmann, Larry. "Malthusianism and the Terror of Scarcity." In Making Threats: Biofears and Environmental Anxieties, edited by Betsy Hartmann, pp. 81-98 Lanham: Rowman \& Littlefield, 2005.

Lovins, Amory. Foreword to Capitalism As If the World Matters, by Jonathon Porritt, pp. i-xvi London: Earthscan, 2007.

Lovins, Hunter and Boyd Cohen. Climate Capitalism: Capitalism in the Age of Climate Change. New York: Hill \& Wang, 2011.

Lumley, Sarah and Partick Armstrong. "Some of the Nineteenth Century Origins of the Sustainability Concept.” Environment, Development and Sustainability 6, 3 (2004): 367-378.

Luxemburg, Rosa. The Accumulation of Capital. London: Routledge \& Kegan Paul, 1971.

Malthus, Thomas. An Essay on the Principle of Population. Vol. 1, edited by Patricia James. Cambridge: Cambridge University Press, 1989 [1803].

- An Essay on the Principle of Population Vol. 1. Available at http://books.google.co.uk/books? id=aMOHWyd5UQcC\&printsec=frontcover\& $\mathrm{dq}=$ malth us $+\% 2 B+\% 22$ echo+library\%22\&hl=en\&ei=1PriTtfaIonE8gP5oI2gBA\&sa=X\&oi=book_r esult $\& c t=$ result $\&$ resnum $=1 \&$ ved $=0 C D c Q 6 A E w A A \# v=$ onepage $\& q=$ malthus $\% 20 \% 2 \mathrm{~B} \% 20$ \%22echo\%20library\%22\&f=false 2006 [1803]. Accessed July 18, 2011.

- An Essay on the Principle of Population. Vol. 2, edited by Patricia James. Cambridge: Cambridge University Press, 1989 [1803].

—. An Essay on the Principle of Population. Vol. 3. London: John Murray, 1817.

- Principles of Political Economy. Second edition. London: William Pickering, 1836.

Matthaei, Julie. "Rethinking Scarcity: Neoclassicism, NeoMalthusianism, and NeoMarxism." Review of Radical Political Economics 16, 2/3 (1984): 81-94.

McNally, David. Against the Market: Political Economy, Market Socialism, and the Marxist Critique. London: Verso, 1993.

Meadows, Donella, Dennis L. Meadows, Jørgen Randers, and William W. Behrens III., The Limits to Growth: A Report for the Club of Rome's Project on the Predicament of Mankind. Washington D.C.: Potomac Associates, 1972.

Mehta, Lyla. Introduction to The Limits to Scarcity: Contesting the Politics of Allocation, edited by Lyla Mehta, pp. 1-10. London: Earthscan, 2010.

Mészáros, István. Social Structure and Forms of Consciousness, Volume II: The Dialectic of Structure and History. New York: Monthly Review Press, 2011.

Mirowski, Philip. The Birth of the Business Cycle. New York: Garland Publishing, 1985.

—_. "Energy and Energetics in Economic Theory: A Review Essay." Journal of Economic Issues 22, 3 (1988): 811-830.

Nitti, Francesco. Population and the Social System. New York: Arno Press, 1976 [1894].

O'Flynn, Micheal. Profitable Ideas: The Ideology of the Individual in Capitalist Development. Leiden: Brill, 2009.

Pearce, Fred. Peoplequake: Mass Migration, Ageing Nations and the Coming Population Crash. London: Eden Project Books, 2010.

Perelman, Michael. "Marx, Malthus, and the Concept of Natural Resource Scarcity." Antipode 4, 1 (1979): 80-91.

Polanyi, Karl. "The New Social Order-From the Point of View of Christian principles." Unpublished manuscript. Karl Polanyi Archive. Concordia University. Folder 21, file 2, 1936.

—. "Fragments." Karl Polanyi Archive. Folder 23, file 6, n.d.. "Letter to Moses Finley, 18 October." Karl Polanyi Archive. Folder 49, file 2, 1953. 
—. Draft manuscript, "Trade and Market in the Early Empire." Unpublished. Karl Polanyi Archive. Folder 38, file 8, 1956.

- The Great Transformation: The Political and Economic Origins of Our Time. Boston: Beacon Press, 1957.

—. Draft manuscript, "New Frontiers in Economic Thinking." Karl Polanyi Archive. Folder 20, file 7, late 1950s.

—. Primitive, Archaic, and Modern Economies, ed. George Dalton, New York: Anchor Books, 1968.

- The Livelihood of Man. New York: Academic Press, 1977.

—. "Über die Freiheit." In Chronik der großen Transformation, Band 3, edited by Michele Cangiani et al., pp. 137-170. Marburg: Metropolis, 2005.

Porritt, Jonathon. Capitalism as If the World Matters. London: Earthscan, 2005.

—. Capitalism as If the World Matters. Revised edition. London: Earthscan, 2007.

Rayner, Steve. Foreword to The Limits to Scarcity: Contesting the Politics of Allocation, edited by Lyla Mehta, pp. xvii-xxi. London: Earthscan, 2010.

Richards, Eric. A History of the Highland Clearances, Volume 2: Emigration, Protest, Reasons. Beckenham: Croom Helm, 1985.

Rist, Gilbert. The Delusions of Economics: The Misguided Certainties of a Hazardous Science. London: Zed Books, 2011.

Romani, Roberto. "The Republican Foundations of Sismondi's Nouveaux principes d'economie politique." History of European Ideas 31, 1 (2005): 17-33.

Samuel, Sajay and Jean Robert. "Water Can and Ought to Run Freely: Reflections on the Notion of 'Scarcity' in Economics." In The Limits to Scarcity: Contesting the Politics of Allocation, edited by Lyla Mehta, pp.109-126. London: Earthscan, 2010.

De Sismondi, J.C. Simonde. New Principles of Political Economy. New Brunswick: Transaction, 1991 [1818].

Smith, Adam. An Inquiry into the Nature and Causes of the Wealth of Nations. Oxford: Oxford University Press, 1993 [1776].

-The Theory of Moral Sentiments. Harmondsworth: Penguin, 2009 [1790].

The Paula Gordon Show. "Hyper Efficient." Available at www.paulagordon.com/shows/lovins/ n.d. Accessed July 18, 2011.

Thompson, William. An Inquiry into the Principles of the Distribution of Wealth Most Conducive to Human Happiness; Applied to the Newly Proposed System of Voluntary Equality of Wealth. London: Longman et al., 1824.

Townsend, Joseph. A Dissertation on the Poor Laws, by a Well-wisher to Mankind. Berkeley: University of California Press, 1971 [1786].

Waldstreicher, David, ed. A Companion to Benjamin Franklin. Oxford: Blackwell, 2011.Wolin, Sheldon. Politics and Vision: Continuity and Innovation in Western Political Thought. Boston: Little, Brown, 1960.

Xenos, Nicholas. Scarcity and Modernity. London: Routledge, 1989. 